\title{
Kinetics of Chromium Sorption on Biomass Fungi from Aqueous Solution
}

\author{
${ }^{1}$ Louhab Krim, ${ }^{1}$ Sahmoune Nacer and ${ }^{2}$ Goma Bilango \\ ${ }^{1}$ Environment Department. Faculty of Engineer Sciences \\ University of Boumerdes, 35000 - Boumerdes - Algeria \\ ${ }^{2}$ Ecole des mines d'Albi - Carmaux - Albi France
}

\begin{abstract}
The kinetics of chromium ions sorption from aqueous solution on fungi biomass have been investigated in a batch system. The experimental data were analysed based on an intraparticle diffusion equation and a pseudo-second-order mechanism, in order to predict the constant rate of sorption and the equilibrium capacity with the effect of initial chromium ions concentration, temperature and initial solution $\mathrm{pH}$. The results indicate that the sorption mechanism is described by a pseudo-second order equation. Intraparticule diffusion was signifiant in the lower concentration systems. The sorption of chromium onto the biomass fungi sorbent is favoured at higher concentrations of chromium solution, low temperatures. An activation energy of sorption was evaluted as $11.7 \mathrm{Kj} . \mathrm{mol}-1$ for the sorption of chromium ions on fungi biomass. The results show that the sorption of the chromium ions on fungi biomass is exothermic nature process.
\end{abstract}

Keywords: Adsorption, chromium, kinetics, fungi biomass, intraparticle diffusion, activation energy.

\section{INTRODUCTION}

Increased industrialisation and human activities have impacted on the environment through the disposal of waste containing heavy metals. electroplating and leather industries, contribute such a kind of waste ${ }^{[1]}$.

The removal of the chromium ions from industrial wastewater is an important problem to be solved. Chromium is considered as priority pollutants because of their high toxicity at low concentrations ${ }^{[1,2,3]}$. Microorganisms including bacteria, algae, fungi and yeast are found to be capable of efficiently accumulating heavy metals ${ }^{[2-5]}$. Bioadsorption mechanisms involved in the process may include ion exchange, co-ordination, complexation, chelation, adsorption and microprecipitation ${ }^{[6,7]}$. Streptomyces remosus, a filamentous fungus can accumulate chromium ${ }^{[1-6]}$. These properties are attributed to the high content of complexing functional groups in their cellular wall (e.g. amino, amide, hydroxyl, carboxyl, sulfhydryl, phosphate radicals) ${ }^{[8]}$. The interest in the potential utlization of fungal biomass as a biosorbent is increasing due to the need for economical and efficient adsorbents to remove chromium ions from wastewater. However, information on fungal interacting with chromium ions is still limited. Fourest and Roux ${ }^{[6]}$ have used mucor meihi biomass to remove chromium from tanning effluent, and observed that the maximum removal of chromium occurred at an initial $\mathrm{pH}$ of 5 for the biomass powder treated by hydroxide sodium. The authors ${ }^{[1,8-11]}$ have studied the adsorption characteristics of chromium ions on the fungal mycelium of Streptomyces remosus. Their results showed that a the adsorption rate is very rapid at the beginning of the process, then the rate shows as equilibrium is approached. The physicochemical mechanisms in the biosorption are complex, no simple theory of adsorption could adequately describe experimental results. Several groups of researchers ${ }^{[12-15]}$ have described the reaction order of sorption in metal-biosorbent systems using various kinetic models. Traditionally, kinetics have been described by the Lagergren first-order equation ${ }^{[16]}$. However, it was reported that a pseudo-second-order model provides a mono-appropriate description of the adsorption of chromium ions to peat and Chlorella vulgaris ${ }^{[17]}$ than does a first-order equation.

The sorption of Chromium ions from aqueous solution onto fungi biomass (streptomycine rimosus) was studied in this paper, and the effect of initial chromium concentration, temperature and initial solution $\mathrm{pH}$ were investigated. An intraparticular diffusion and pseudosecond-order model was developed and was used to analyse the data for the sorption of chromium ions onto fungi biomass.

Corresponding Author: Louhab Krim, Environment Department. Faculté of Enginner Sciences. University of Boumerdes, 35000 -Boumerdes-Algeria 


\section{MATERIALS AND METHODS}

The experiments are carried out with the laboratory environment and pollution of the university of Boumerdes -Algeria

Biomass preparation: The biomass used is the streptomycine rimosus, coming from the SAIDALcomplex manufacturing unit of antibiotics MedeaAlgeria. This antibiotic by-product is a mud of Mycelium resulting from the extraction of the fermented gelatine meat-broth for the manufacture of the oxytetracycline.

This biomass underwent a pre-treatment which consists of repeated washing with distilled water until the elimination of the impurities, drying in a drying oven during 48 hours, then crushing and sifting to obtain an easily storable powder of granulometry ranging from 100 to 700 micrometers. Then a chemical treatment is underwent which consists in introducing the dried biomass into a solution of hydroxide sodium of $0.01 \mathrm{~N}$ concentration. The biomass is maintained in suspension by agitation during $30 \mathrm{~min}$ at ambient temperature, repeatedly filtered and washed with distilled water then dried in the drying oven at $50^{\circ} \mathrm{C}$ during 2 hours and an air-tight container.

Chromium uptakes: Stock solutions of chromium (III) (3g/l) were prepared in distilled water using $\mathrm{Cr}_{2}\left(\mathrm{SO}_{4}\right)_{3}$; all working solutions were prepared by diluting the stock solution with distilled water. A volume of $100 \mathrm{ml}$ of $\mathrm{Cr}_{2}\left(\mathrm{SO}_{4}\right)_{3}$ solution with a concentration ranging from 126 to $2600 \mathrm{mg} / \mathrm{l}$ was placed in a $250 \mathrm{ml}$ conical flask and set at $\mathrm{pH}$ 4.8. $0.3 \mathrm{~g}$ of the biomass fungi (streptomycin rimosus) was accurately weighed and added to the solution. The conical flask was then shaken at a constant speed of $300 \mathrm{rpm}$ in a shaking water bath with temperatures 20,30 , and $40^{\circ} \mathrm{C}$, respectively After shaking the flasks for $2 \mathrm{~h}$, the biomass fungi was separated by filtration by atomic was analysed for remaining chromium using a Perkin Elmer 2380 atomic absorption spectrophometer.

\section{RESULTS AND DISCUSSION}

Pseudo-second order model: In order to investigate the mechanism of adsorption, the adsorption reaction order of chromium were determined using a pseudo-secondorder mechanism expression ${ }^{[13-15,18]}$. The sorption kinetics may be described as being pseudo-secondorder. The differential equation is

$$
\mathrm{dq}_{\mathrm{t}} / \mathrm{dt}=\mathrm{k}\left(\mathrm{q}_{\mathrm{e}}-\mathrm{q}_{\mathrm{t}}\right)^{2}
$$

Where $\mathrm{k}$ is the rate constant of sorption $\left(\mathrm{g} \cdot \mathrm{mg}^{-1} \mathrm{~min}^{-1}\right)$, qe the amount $\left(\mathrm{mg}_{\mathrm{g}} \mathrm{g}^{-1}\right)$ of chromium ions sorbed onto the surface of the fungi biomass at any time.
Separating the variables in the equation above gives

$$
\mathrm{dq}_{\mathrm{t}} /\left(\mathrm{q}_{\mathrm{e}}-\mathrm{q}_{\mathrm{t}}\right)^{2}=\mathrm{kdt}
$$

Integrating this for the boundary conditions $t=0$ to $t$ and $\mathrm{q}_{\mathrm{t}}=0$ to $\mathrm{q}_{\mathrm{t}}$, gives

$$
1 /\left(\mathrm{q}_{\mathrm{e}}-\mathrm{q}_{\mathrm{t}}\right)=1 / \mathrm{q}_{\mathrm{e}}+\mathrm{kt}
$$

Thus, a plot of $1 /\left(q_{e}-q_{t}\right)$ against $t$ of Eq.(3) should give a linear relationship with a slop of $\mathrm{k}$ and an intercept of $1 / \mathrm{q}_{\mathrm{e}}$

As $\mathrm{h}$ can be regardes as the initial sorption rate, then :

$$
\mathrm{h}=\mathrm{k} / \mathrm{q}_{\mathrm{e}}^{2}
$$

Intraparticle diffusion model: Theorecal treatments of intraparticle diffusion yield rather complex mathematical relationships which differ in forms as functions of the geometry of the sorbent particle. A functional relationship common to most treatments of intraparticle diffusion is that uptake varies almost proprtionately with the half - power of time $t^{0.5}$, rather than $t$; a nearly linear variation in the quantity sorbed with $t^{0.5}$ is predicted for a large initial fraction of reactions controlled by rates of intraparticle diffusion. Good linearization of the data is observed for the initial phase of the reaction in accordance with expected behavior if intraparticle diffusion is the rate-limiting step ${ }^{[18]}$. According to Weber and Morris ${ }^{[17]}$ if the rate limiting step is intraparticle diffusion, a plot of solute sorbed against the square root of the contact time should yield a straight line passing through the origine ${ }^{[19]}$. The most-widely applied intraparticle diffusion equation for sorption system is given by Weber and Morris ${ }^{[17]}$ :

$\mathrm{q}_{\mathrm{t}}=\mathrm{k}_{\mathrm{i}} \mathrm{t}^{0.5}$

where $k_{i}$ is the intraparticle diffusion rate constant (mg.g $\mathrm{gin}^{-1} \operatorname{mon}^{0.5}$

The $\mathrm{k}_{\mathrm{i}}$ values inder different conditions were calculated from the slopes of the straight-line portions of the respective plots.

Effect of initial chromium concentration: The rate of chromium sorption on the biomass fungi was determined as a function of the initial chromium concentration using initial concentrations of 455, 1076, 1630 , and $2600 \mathrm{mg} / \mathrm{l}$. The initial sorption rate incresed from 4.88 to $399.70 \mathrm{mg} \cdot \mathrm{g}^{-1} \mathrm{~min}^{-1}$, the equilibrium sorption ( Figure.1) increased from 22.1 to $64.2 \mathrm{mg} / \mathrm{g}$ and the value of rate constant (Figure.2) increased from 0.010 to $0.097 \mathrm{mg} \cdot \mathrm{g}^{-1} \mathrm{~min}^{-1}$ with an increase in the initial concentration of chromium (III) from 455, 1076, 1630, and $2600 \mathrm{mg} / \mathrm{l}$. This could have been due to the 


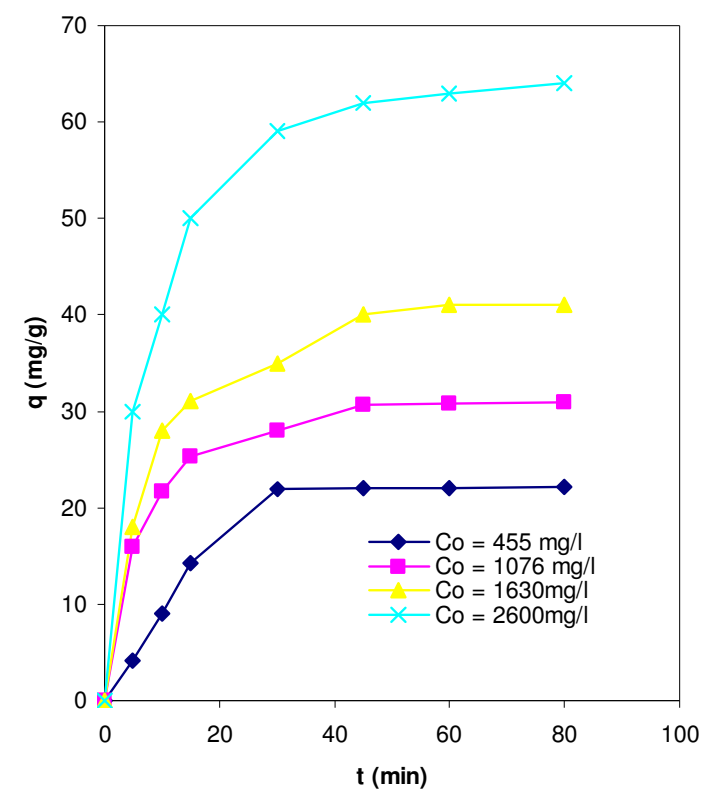

Fig.1: Effect of initial concentration of chromium on its sorption onto fungi biomass

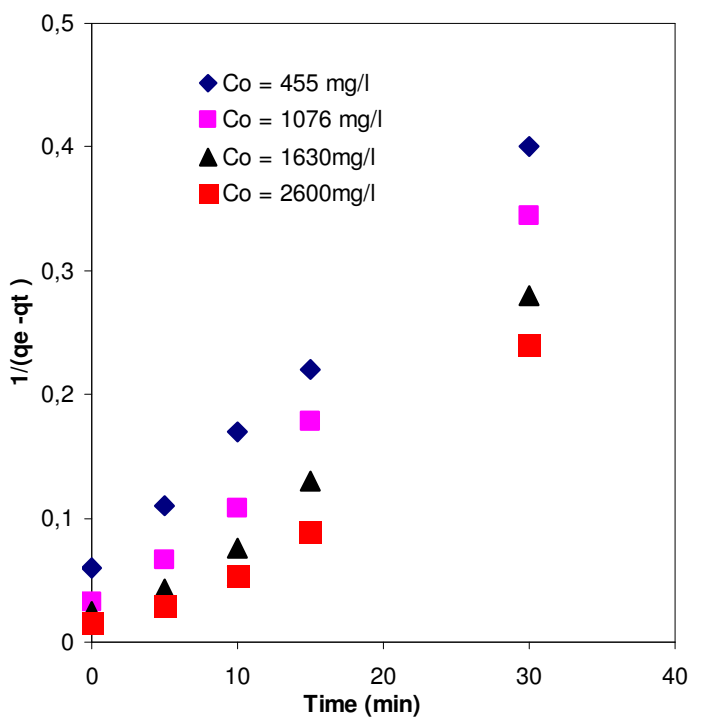

Fig.2: plot of 1/ $\left(q_{e}-q_{t}\right)$ against $t$ for chromium sorption at various initial chromium concentrations

driving force of higher concentrations ${ }^{[20]}$. The obseved dependence of the rate on the initial concentration of chromium(III) indicates that removal of chromium (III) from aqueous solution should present no significant obstacl, since sorption relative to the initial concentration of chromium is more rapid the more dilute the solution is. Fig.1 shows plot of the experimental data points for the sorption of chromium (III) by fungi biomass as function of time. These plots show that, for all initial chromium concentrations, the amount of chromium (III) sorbed increased rapidly with time at the beginning and became very slow towards the end of the process.

The plots also demonstrate that the sorption increased for lower initial chromium concentration at any specific time. These plots show that, for all initial chromium concentrations, the amount of chromium (III) sorbed increased rapidly with time at the beginning and became very slow towards the end of the process. The plots also demonstrate that the sorption increased for lower initial chromium concentration at any specific time. Furthermore, a large fraction of the total amount of chromium (III) was removed within a short period of time. There was also an effect on the contact time required to reach saturation due to the variation in the initial chromium concentration.

The pseudo-second-order rate constant, $\mathrm{k}$, was found to decrease non-linearity with the increasing initial concentration of chromium within the rang from of 445 to $2600 \mathrm{mg} / \mathrm{l}$.

Intraparticle diffusion is characterised by dependence between the sorption capacities at any reaction time, $q_{\mathrm{t}}$, and the square root of time, with the slope of the relationship being the intraparticle diffusion rate parameter expressed in Eq. (5). As can be seen from a typical set of data for the systems investigated (Fig. 3), the valueof the intraparticle diffusion rate constant increased from 2.82 to $6.84 \mathrm{mg} \cdot \mathrm{g}^{-1} \mathrm{~min}^{0.5}$ with an increase in the initial concentration of chromium (III) from 455, 1076, 1630, and $2600 \mathrm{mg} / \mathrm{l}$, the relationships are not linear for the entire range of reaction time. This non-linearity has been reported previously ${ }^{[20,21]}$ and has been explained in terms of both diffusion processes having an effect on the sorption. It is clear from Fig. 3 that the relationships yield a straight line passing through the origin for the beginning part, and this was more likely to occur at lower initial chromium concentrations. It may be concluded that the ratelimiting step is intraparticle diffusion in the initial period of the reaction.

Accordingly, a correlation was empirically made of the pseudo-second-order rate constant, $k$, as a function of the initial concentration of chromium as follows:

$$
\mathrm{k}=\mathrm{mC}_{0}{ }^{\mathrm{n}}
$$

McKay et al ${ }^{[19]}$ reported that in the case of sorption of Acid Blue 25 using chitin, $\mathrm{n}$ centers around 0.5 values, confirming that intraparticle diffusion is a prominent factor in the sorption process. In cases of sorption of larger molecular dyes, the sorption rate was slower and intraparticle diffusion was the rate-limiting step ${ }^{[22,23]}$. Conversely, in cases of sorption of metal ions, the sorption rate was generally faster and was not affected 
Am. J. Environ. Sci., 2 (1): 27-32, 2006

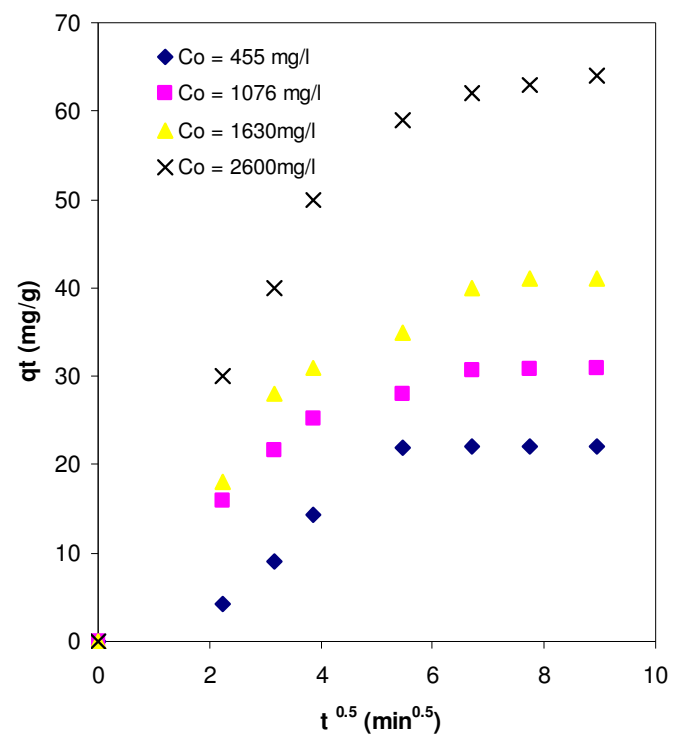

Fig.3. Plot of sorption capacity vs. The square root of time for chromium sorption onto fungi biomass

by intraparticle diffusion ${ }^{[24]}$. In addition, a negative value of $\mathrm{n}$ was reported for the chromium sorption on fungi biomass for which the second-order chemisorption is important ${ }^{[25]}$.

The results from this study suggest that the relationship between the pseudo-second-order rate constant, $\mathrm{k}$, and the initial chromium concentration follows Eq. (5) with a coefficient of determination of 0.992 as shown in the following equation:

$$
\mathrm{k}=3.16 \times 10^{-6} \mathrm{C}_{0}{ }^{1.33}
$$

The value of $n$ (1.33) differs from 0.5 based on intraparticle diffusion. This indicates that the kinetics of chromium sorption using fungi biomass is described by a pseudo-second-order expression rather that by intraparticle diffusion, and intraparticle diffusion is not the rate-limiting step.

Effect of temperature: The sorption experiments were repeated at various temperatures in the range of 293 to $313 \mathrm{~K}$ with the biomass fungi. The equilibrium sorption capacity of chromium decreases from 65.0 to $43.1 \mathrm{mg} / \mathrm{g}$ with increasing temperature from 293 to $313 \mathrm{~K}$, that indicates a low temperature favors chromium removal by sorption onto the biomass fungi sorbent. This may be due to a tendency for the chromium ions to escape from the solid phase to the bulk phase with an increase in temperature of the solution [26, 27]. A similar observation was also reported in the study on the sorption of chromium onto china clay and wollastonite ${ }^{[28]}$. The values of rate constant, $k$, were found to slightly

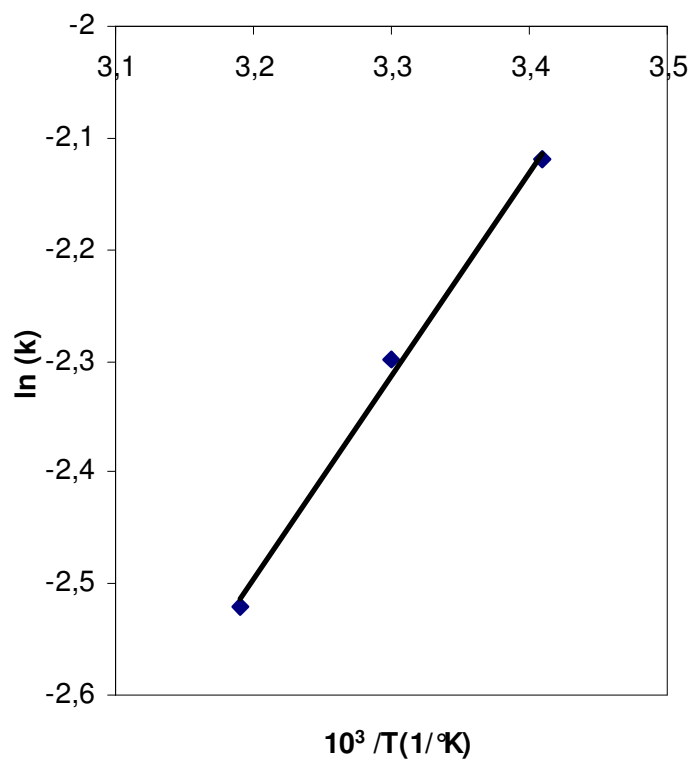

Fig.4. Plots of $\ln (\mathrm{k})$ againdt reciprocal temperature for chromium sorption onto a fungi biomass $\mathrm{Co}=455 \mathrm{mg} / \mathrm{l} ;$ Biomass concentration $=3 \mathrm{~g} / \mathrm{l}$; $\mathrm{p} \mathrm{Hi}=4.8$ )

decrease from 0.12 to $0.08 \mathrm{mgg}^{-1} \mathrm{~min}^{-1}$ for an increase in solution temperature from 293 to $313 \mathrm{~K}$ for the sorption of chromium. A linear relationship between the pseudo rate constant and temperature was observed with a correlation coefficient of 0.996 . The $k$ values were plotted as a function of the reciprocal of the Kelvin temperature. Linear variations were observed as shown in Fig. 4.

Therefore, the sorption rate constant may be expressed as a solution function of temperature by the following relationship:

$$
\mathrm{k}=\mathrm{k}_{\mathrm{o}} \exp (-\mathrm{E} / \mathrm{RT})
$$

where $\mathrm{k}$ is the rate constant of sorption $\left(\mathrm{mg} \cdot \mathrm{g}^{-1} \mathrm{~min}^{-1}\right)$; $\mathrm{k}_{\mathrm{o}}$ is the temperature independent factor $\left(\mathrm{mg} \cdot \mathrm{g}^{-1} \mathrm{~min}^{-1}\right) ; \mathrm{E}$ is activation energy of sorption $\left(\mathrm{kJ} \mathrm{mol}^{-1}\right) ; \mathrm{R}$ is the gas constant $\left(8.314 \mathrm{~J} \mathrm{~mol}^{-1} \mathrm{~K}^{-1}\right)$; $\mathrm{T}$ is solution temperature (K).

Thus, the relationship between $\mathrm{k}$ and $\mathrm{T}$ can be represented in an Arrhenius form as:

$$
\mathrm{k}=2.45 \times 10^{-4} \exp (14.71 / 8.314 \mathrm{~T})
$$

From this equation, the rate constants of sorption, $\mathrm{k}_{0}$, is $2.45 \times 10^{-4} \mathrm{mg} \cdot \mathrm{g}^{-1} \mathrm{~min}^{-1}$ and the activation energy of sorption, E, is $-11.7 \mathrm{~kJ} \mathrm{~mol}^{-1}$. Since sorption is an exothermic process, it would be expected that an increase in solution temperature would result in a decrease in sorption capacity. 


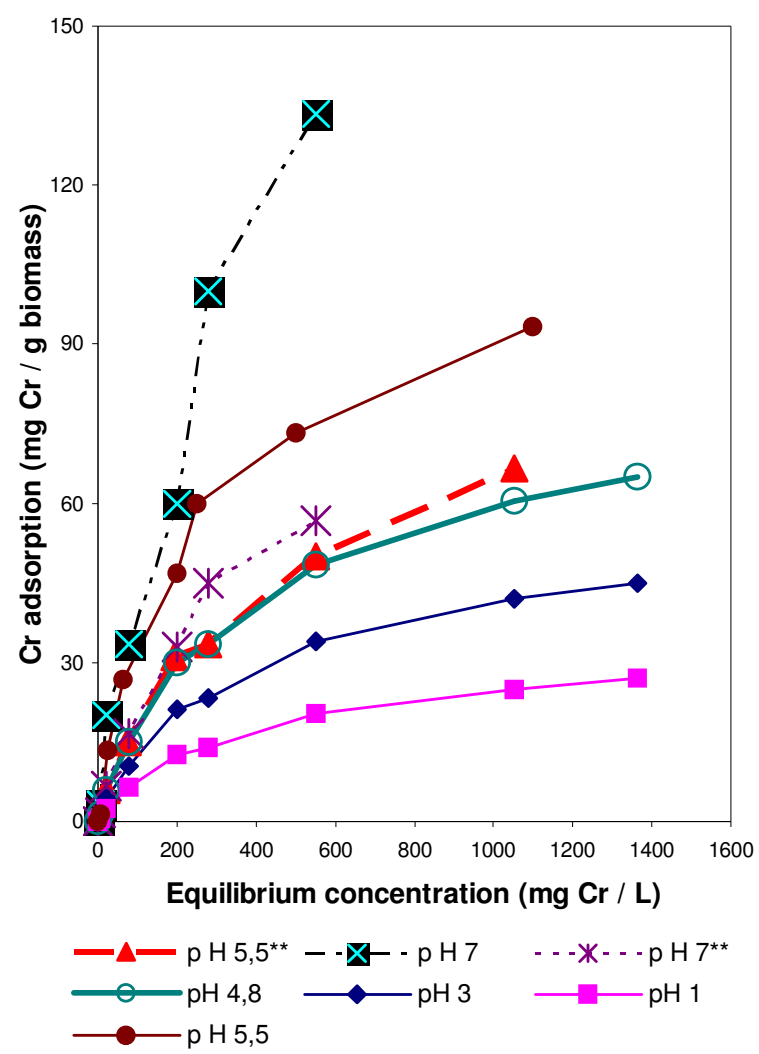

Fig.5. Effect of $\mathrm{pH}$ and influence of precipitation on uptake (** indicates where precipitations effects have been subtracted)

Effect of Initial pH: The effect of $\mathrm{pH}$ on the adsorption capacity of chromium with biomass of streptomycine rimosus was identified, when the $\mathrm{pH}$ value was raised from 1 to 4.8, the adsorption capacity was enhanced significantly from 27 to $64 \mathrm{mg} / \mathrm{g}$ biomass. Absorption studies at $\mathrm{pH} 5.5$ and 7.0 marked precipitation effects augmented the biosorption removal of chromium from solution resulting in apparent sequestration levels of in excess of 93 and $133 \mathrm{mg} / \mathrm{g}$ respectively as illustrated in figure 5. As can be seen in the figure, when the precipitation component is subtracted the net biosorption values are in good agreement with each other and those observed at $\mathrm{pH} 4.8^{[3]}$. The optimal $\mathrm{pH}$ for adsorption of chromium by mycelia by-products of streptomycine rimosus was around 4.8 .

The rate of chromium sorption onto the fungi biomass sorbent will be varied with the available $\mathrm{pH}$ values of solution when ion exchange development and applications is one of the sorption processes.

The $\mathrm{pH}$ values used in these studies are 1.0, 3.0, 4.5, 5.5 and 7.0 for the sorption of chromium with the fungi biomass sorbent. The rate constant, $k$, and
Table.1 Parameters for effect of initial $\mathrm{pH}$ on the sorption of chromium

\begin{tabular}{ccc}
\hline $\mathbf{p H}$ & $\mathbf{q}(\mathbf{m g} / \mathbf{g})$ & $\mathbf{k}\left(\mathbf{m g} \cdot \mathbf{g}^{-\mathbf{1}} \mathbf{~ m i n}^{\mathbf{- 1}}\right)$ \\
\hline 1 & 27 & 0.07 \\
3 & 43 & 0.09 \\
4.8 & 64 & 0.12 \\
\hline
\end{tabular}

the equilibrium capacity, $q_{\mathrm{e}}$, of sorption at various $\mathrm{pH}$ values have been determined and are listed in Table 1.

The removal of chromium from aqueous solution by sorption is highly dependent on $\mathrm{pH}$ of the solution which affects the surface properties of the sorbent.

The sorption capacity for chromium of the fungi biomass sorbent decreased from 27 to $64 \mathrm{mg} \mathrm{g}$ when the $\mathrm{pH}$ of the initial chromium solution was increased from 1.0 to 4.5 (Table 1). However, the chromium removal remained essentially constant within the $\mathrm{pH}$ range of 4.5 to 7.0 . The trend was similar to the sorption of chromium on china clay and the sorption of chromium on kaolinitic clay ${ }^{[29]}$.

\section{CONCLUSION}

The kinetics of sorption of chromium onto biomass fungi sorbent were correlated by a pseudo-second-order expresion. Intraparticle diffusion was the rate-limiting step only for lower chromium ion concentrations. The equilibrium rate constant, and the initial chromium rate increased with an increase in the initial chromium concentration. The sorption of chrolium ions on fungi biomass is of an exothermic nature. It was noted that an increase in the temperature resulted in lower chromium loading per unit weigt of the fungi biomass

\section{REFERENCES}

1. Aksu Z and Kustal T., 1990. A comparative study for biosorption characteristics of heavy metals ions with C. vulgaris. Environ. Technol., 11: 979-987.

2. Gadd GM., 1987. Fungal response towards heavy metals. In: Herbert RA and Codd GA (eds.) Microbes in Extreme Environmentals. Academic Press, London. 84-109.

3. Gupta, G.S., S.P. Shukla, G. Prasad, and V.N. Singh., 1992. China Clay as an Adsorbent for Dye House Wastewaters. Environ. Technol., 13: 925936 .

4. Mullen MD, Wolf DC, Freeis FG, Beveridge TJ, Flemming CA and Bailly GW., 1989. Bacterial sorption of heavy metals. Appl. Environ. Microbiol., 55: 3143-3149. 
5. Atkinson BW, Bux F and Kasan HC., 1998. Consideration for application of biosorption technology to remediate metal-contami-nated industrial effluents. Water SA ., 24: 129-135.

6. Guibal E, Roulph C and Cloirc PL., 1992. Uranium biosorption by a filamentous fungus Mucor miehei: $\mathrm{pH}$ effect on mechanisms and performances of uptake. Water Res., 26: 1139-1145.

7. Fourest E and Roux JC., 1992. Heavy metal biosorption by fungal mycelial byproducts: Mechanisms and influence of $\mathrm{pH}$. Appl. Microbiol. Biotechnol., 37: 399-403.

8. Brady, J.M and J.M. Tobin., 1995. Binding of hard and soft metal ions to Rhizopus arrhizus biomass. Enzyme. Micob. Technol., 17: 791-796.

9. Nourbash M., Sag Y., Ozer D., Aksu Z., Kustal T. and Caglar A., 1994. A comparative study of various biosorbents for Chromium(VI) ions from industrial waste water. Process Biochem., 29: 1-5

10. Bai, R.S and Abraham. T.E., 2001. Biosorption of $\mathrm{Cr}(\mathrm{VI})$ from aqueous solution by Rhizopus nigricans. Bioresour. Technol., 79: 73-81.

11. Sag. Y and Kutsal. T., 1996. Fully competitive biosorption of chromium(VI) and iron(III) ions from binary metal mixtures by R. arrhizus: use of the competitive Langmuir model. Process Biochem., 31: 573-585.

12. Wu. F.C, Tseng.R.L, Juang.R.S., 2001. Kinetic modelling of loquide-phase adsorption of reactive dyes and metal ions on chitosen. Water Research., 35: 613-618.

13. Yuh-Shan Ho and Augustine E. Ofomaja., 2005. Effects of calcium competition on lead sorption by palm kernel fibre. Journal of Hazardous Materials., B120: 157-162.

14. Yuh-Shan Ho and Augustine E. Ofomaja., 2005. Kinetics and thermodynamics of lead ion sorption on palm kermel fibre from aqueous solution. Process Biochemistry., 40: 3455-3461.

15. Yuh-Shan Ho, G. McKay., 2000. The kinetics of sorption of divalent metal ions onto sphagnum moss peat. Water Res., 34: 734-742.

16. Periasamy. K, Namasivayam. C., 1995. Adsorption of $\mathrm{Pb}$ (II) by peanut hull carbon from aqueous solution. Sep. Sci. Technol., 30: 2223-2237
17. Brady, Stoll A and Dungan JR., 1994. Biosorption of heavy metal cations by non-viable yeast biomass. Environ. Technol., 15: 429-438.

18. Weber. W. J, J.C.Morris., 1963. Kinetics of adsorption on carbon from solution. J. Sanit. Eng. Div. ASCE., 89: 31-59.

19. G. McKay, M.S. Otterburn, A.G. Sweeney., 1980. The removal of colour from effluent using various adsorbents. III Silica: rate processes. Water Res., 14: $15-20$.

20. G.S. Gupta, G. Prasad, V.N. Singh., 1990. Removal of chrome dye from aqueous solutions by mixed adsorbents: fly ash and coal. Water Res., 24: 45-50.

21. Y.S. Ho, G. McKay., 1998. Kinetic models for the sorption of dye from aqueous solution by wood. Process Saf. Environ. Protect., 76B: 183-191.

22. D.N. Jadhav, A.K. Vanjara., 2004. Adsorption kinetics study: Removal of dyestuff effluent using sawdust, polymerized sawdust and sawdust carbonII. Indian J. Chem. Technol., 11: 42-50.

23. M. Prasad, S. Saxena., 2004. Sorption mechanism of some divalent metal ions onto low-cost mineral adsorbent., Ind. Eng. Chem. Res., 43: 1512-1522.

24. Y.S. Ho, G. McKay., 1998. Kinetic model for lead(II) sorption on to peat. Adsorpt. Sci. Technol., 16: 43-255.

25. Panday, K.K., G. Prasad, and V.N. Singh., 1984. Removal of $\mathrm{Cr}(\mathrm{VI})$ from Aqueous Solution by Adsorption on Fly Ash Wollastonite. J. Chem. Technol. Biotechnol., 34: 367-374 .

26. Gupta, V.K., D. Mohan, and S. Sharma., 1998. Removal of Lead from Wastewater Using Bagasse Fly Ash-A Sugar Industry Waste Material. Sep. Sci. Technol., 33: 1331-1343 .

27. Yadava, K.P., B.S. Tyagi, and V.N. Singh., 1991. Effect of Temperature on the Removal of Lead (II) by Adsorption on China Clay and Wollastonite. J. Chem. Technol. Biotechnol., 51: 47-60.

28. Gupta, G.S., S.P. Shukla, G. Prasad, and V.N. Singh., 1992. China Clay as an Adsorbent for Dye House Wastewaters," Environ. Technol. 13: 925936 .

29. Orumwense, F.F.O., 1996. Removal of Lead from Water by Adsorption on a Kaolinitic Clay. J. Chem. Technol. Biotechnol., 65: 363-369. 